\title{
Antiproliferative and genotoxic effects of nature identical and artificial synthetic food additives of aroma and flavor
}

\author{
R. D. M. Nunes ${ }^{a}$, I. M. S. Sales ${ }^{a}$, S. I. O. Silva ${ }^{a}$, J. M. C. Sousa $a^{b}$ and A. P. Peron ${ }^{b, c *}$ \\ ${ }^{a}$ Curso de Ciências Biológicas, Departamento de Ciências Biológicas, Universidade Federal do Piauí - UFPI, \\ Campus Senador Helvídio Nunes de Barros, Avenida Cicero Duarte, 950, Bairro Junco, CEP 64600-000, Picos, PI, Brazil \\ 'Departamento de Ciências Biológicas, Universidade Federal do Piauí - UFPI, Campus Senador Helvídio Nunes de \\ Barros, Avenida Cicero Duarte, 950, Bairro Junco, CEP 64600-000, Picos, PI, Brazil \\ cPrograma de Pós-graduação em Genética e Melhoramento - PPGM, Centro de Ciências Agrárias, Campus Ministro \\ Petrônio Portella, Avenida Universitária, Bairro Iningá, lado ímpar, CEP 64049-550, Teresina, PI, Brazil \\ *e-mail: anapaulaperon@ufpi.edu.br
}

Received: August 10, 2015 - Accepted: October 5, 2015 - Distributed: February 28, 2017

\begin{abstract}
This study aimed to analyze the antiproliferative and genotoxic potential of synthetic food flavorings, nature identical passion fruit and artificial vanilla. This assessment used root meristem cells of Allium cepa L., in exposure times of 24 and 48 hours and using doses of 0.2; 0.4 and $0.6 \mathrm{~mL}$. Roots were fixed in Carnoy's solution, hydrolyzed in hydrochloric acid, stained with acetic orcein and analyzed with optical microscope at 400× magnification, 5,000 cells for each treatment. For data analysis, it was used Chi-square test at $5 \%$. Doses of $0.2 \mathrm{~mL}$ at ET $48 \mathrm{~h} ; 0.4$ and $0.6 \mathrm{~mL}$ at ET 24 and $48 \mathrm{~h}$ of passion fruit flavor, and the three doses of the vanilla flavor at ET 24 and $48 \mathrm{~h}$ significantly reduced the cell division rate in the meristems of roots, proving to be cytotoxic. Doses of $0.2 ; 0.4$ and $0.6 \mathrm{~mL}$ of the passion fruit additive, and the three doses of vanilla tested, in the two exposure times, induced mitotic spindle changes and micronuclei formation in the cells of the test organism used, proving to be genotoxic. Therefore, under the studied conditions, flavoring solutions of vanilla and passion fruit, marketed nationally and internationally, significantly altered the functioning of the cell cycle in root meristem cells of $A$. серa.
\end{abstract}

Keywords: food flavorings, cell cycle, cell changes, meristematic cells.

\section{Efeito antiproliferativo e genotóxico de aditivos alimentares de aroma e sabor sintéticos, dos tipos idêntico ao natural e artificial}

\section{Resumo}

Neste trabalho teve-se por objetivo analisar o potencial antiproliferativo e genotóxico de aromatizantes alimentares sintéticos, idêntico ao natural de Maracujá, e artificial de Baunilha. Esta avaliação foi realizada por meio das células meristemáticas de raízes de Allium cepa L., nos tempos de exposição de 24 e 48 horas e nas doses de 0,2; 0,4 e 0,6 ml. As raízes foram fixadas em solução de Carnoy, hidrolisadas em ácido clorídrico e coradas com orceína acética. Analisou-se, em microscópio óptico em aumento de $400 \times, 5.000$ células por grupo tratamento, e utilizou-se o teste estatístico Qui-quadrado a 5\% para análise dos dados. Verificou-se que as doses de 0,2 $\mathrm{ml}$, no TE $48 \mathrm{~h} ; 0,4$ e 0,6 ml, nos TE 24 e 48 h, do aromatizante de Maracujá, e as três doses analisadas, nos TE 24 e 48 h, do aditivo de Baunilha reduziram significativamente o índice de divisão celular dos meristemas de raízes, mostrando-se citotóxicas. As doses 0,2; 0,4 e 0,6 $\mathrm{ml}$ do aditivo de Maracujá, e a de $0,6 \mathrm{ml}$ do aromatizante de Baunilha, nos dois tempos de exposição considerados, induziram alterações de fuso mitótico e micronúcleos as células do organismo de prova utilizado, mostrando-se genotóxicas. Portanto, nas condições analisadas, as soluções aromatizantes de Baunilha e Maracujá, comercializadas nacional e internacionalmente, alteraram significativamente o funcionamento do ciclo celular das células meristemáticas de raízes de $A$. cepa.

Palavras-chave: aromatizantes alimentares, ciclo celular, alterações celulares, células meristemáticas.

\section{Introduction}

Flavorings are food additives with aromatic properties capable of providing or enhancing the aroma and flavor of food without nutritional purposes. They are classified as natural, synthetic nature-identical and synthetic artificial (Koca et al., 2015). They have a complex chemical composition consisting of several classes of chemical 
compounds such as diluents, antioxidants, defoamers, preservatives, emulsifiers, stabilizers, acidity regulators, flavor enhancers, anti-caking agents, dyes, and extraction and processing solvents. Such a composition is approved for use worldwide by the European Food Safety Authority (EFSA) (Xu et al., 2015) and in Brazil by the National Sanitary Surveillance Agency (ANVISA) (Brasil, 2007).

Synthetic food additives of aroma and flavor, although essential for the food industry, are considered a controversial advancement in the area of food technology by many healthcare experts (Koca et al., 2015). These professionals reported that these ingredients contribute significantly to the dietary impoverishment and development of diseases such as allergies and alterations in the functioning of the digestive tract (Konishi et al., 2014, Oliveira et al., 2013). However, technical documents of food surveillance agencies do not specify which specific compounds and their concentrations are present in the composition of these additives and nor the Acceptable Daily Intake (ADI) of the flavorings for the population (Konishi et al., 2014). The information of the chemical constituents present in the formulation is also not presented on the labels of flavoring solutions marketed nor at the specialized sites selling these food additives.

However, ANVISA (Brasil, 2007) states that high doses of flavorings cause irritant and narcotic actions, and produce chronic toxicity to the digestive tract when taken long term, but the regulations of this agency does not mention what concentrations and what flavorings determined such a conclusion. It also highlights the continuing need for toxicological studies involving food additives in general, and emphasizes that the results obtained from these analyses are guiding the development or modification of action strategies of food safety agencies and activities of professionals responsible for monitoring food and nutrition of the population (Brasil, 2007; Konishi et al., 2014).

According to the International Programme on Chemical Safety (IPCS) and the United Nations Environment Programme (UNEP), the root meristematic zone of Allium cepa L. (onion) is an efficient test organism for the preliminary evaluation of toxicity at cellular level (Türkoğlu, 2007; Tabrez et al., 2011; Lacerda et al., 2014). This organism has excellent kinetic properties of proliferation, large chromosomes in reduced number $(2 n=16)$, which facilitates the detection of chromosomal aberrations and abnormalities in the mitotic spindle (Herrero et al., 2012; Cardoso et al., 2014). It also allows the verification of changes in cell division or mitotic index when exposed to chemical compounds with potential cytotoxic action (Caritá and Marin-Morales, 2008; Neves et al., 2014). According to Herrero et al. (2012) and Tabrez et al. (2011), A. cepa system is very effective for initial assessment of cytotoxicity and genotoxicity of chemical compounds or for validation of these conditions after conducting research in other bioassays.

In this context, this study used $A$. cepa root meristem roots to evaluate the antiproliferative and genotoxic potential of synthetic flavorings Passion Fruit and Vanilla. These flavorings were chosen for analysis because they are widely used in the food industry in the preparation of processed sweet foods, and there is no scientific literature evaluating the toxicity of these flavorings.

\section{Material and Methods}

This work was conducted at the Laboratory of Animal and Plant Cytogenetics, Campus Senador Helvídio Nunes de Barros, Federal University of Piauí, between December 2014 and July 2015.

Flavor and aroma synthetic additives in the liquid form, nature identical of Passion Fruit and artificial of Vanilla, were obtained from an industry in the city of Recife, Pernambuco State, Brazil, specialized in manufacturing and domestic and international marketing of synthetic food additives. The manufacturer suggested, on the label of vials, the use of $1.0 \mathrm{~mL}$ of flavoring solution for $1.0 \mathrm{~kg}$ of mass. Onion bulbs selected for this study weighed on average 200 grams. Thus, proportionally to the recommended, it was initially set for analysis the volume of flavoring (dose) of $0.2 \mathrm{~mL}$. Then, we defined two higher doses, 0.4 and $0.6 \mathrm{~mL}$.

For toxicological analysis, onion bulbs were allowed to root in flasks with distilled water at room temperature $\left( \pm 27^{\circ} \mathrm{C}\right)$ to obtain $2.0 \mathrm{~cm}$ long roots. For the analysis of each treatment group (TG), we used five onion bulbs. The TG established for each flavor were: TG 0.2; TG 0.4 and TG $0.6 \mathrm{~mL}$. Before placing the roots in contact with their respective doses, some roots were collected and fixed to serve as control of the bulb itself. Then, the remaining roots were placed into their respective flavoring solutions for 24 hours, a procedure called 24 hour exposure time (ET $24 \mathrm{~h}$ ). After 24 hours, some roots were removed and fixed. After this, the remaining roots of each onion were returned to their respective solutions where they remained for additional 24 hours, which was called as 48-hour exposure time (ET $48 \mathrm{~h}$ ).

Thereafter, roots were collected and fixed again. The fixation of roots occurred in Carnoy 3: 1 (ethanol: acetic acid) for 24 hours. Three roots per bulb were taken in each collection. On average 03 slides were mounted per bulb, following the protocol proposed by Guerra and Souza (2002), and analyzed under an optical microscope at $400 \times$ magnification. For each onion bulb, we examined 1,000 cells, totaling 5,000 cells for control, ET 24 and ET 48 hours of each TG analyzed.

It was analyzed cells throughout the cell cycle and calculated the number of cells in interphase and in division for each control and exposure time and determined index of cell division or mitotic index (MI). It was also evaluated the toxic potential of doses by means of the number of micronucleated cells, colchicine metaphases, anaphase and telophase bridges. Data were analyzed by Chi-square test at $5 \%$ level.

\section{Results and Discussion}

Importantly, no dilution was performed to define the doses of flavorings, that is, it was tested the toxicity of these additives on A. cepa root meristem directly from 
the original solutions in vials of the products sold in retail trade. This because the additives have complex chemical formulation and so, the concentration and the action of compounds present in these ingredients could be changed if diluted. Also, ET $24 \mathrm{~h}$ and $48 \mathrm{~h}$ were set to evaluate the effect of these additives on more than one cell cycle. It is also important to mention that, according to the Technical Regulation on Flavorings/Aroma approved by ANVISA (Brasil, 1999) and still in force, the formulation of any synthetic food flavoring is standardized worldwide.

Table 1 presents the number of cells in interphase and at different stages of cell division, and the values of mitotic index obtained from meristematic cells of $A$. cepa roots treated with water and food flavorings of Passion Fruit and Vanilla.

The results in Table 1 shows that, at a dose of $0.2 \mathrm{~mL}$ of the additive passion fruit, the cell division index observed for CO and ET $24 \mathrm{~h}$ are statistically similar. For the ET $48 \mathrm{~h}$ of this dose, there has was a sharp reduction in the mitotic index in relation to the respective CO and ET $24 \mathrm{~h}$. For the doses 0.4 and $0.6 \mathrm{~mL}$ of this flavoring, the cell division index of ET $24 \mathrm{~h}$ and ET $48 \mathrm{~h}$ decreased significantly compared to the value observed for their respective controls. Also, for these two doses, the reduction in cell division was more pronounced in the ET $48 \mathrm{~h}$. Thus, for the flavoring of passion fruit, under these analytical conditions, the dose of $0.2 \mathrm{~mL}$ at the ET $48 \mathrm{~h}$, and the doses of 0.4 to $0.6 \mathrm{~mL}$ at the
ET 24 and ET $48 \mathrm{~h}$ promoted a significant antiproliferative effect in the cell test system used.

The results obtained for cells exposed to the flavoring vanilla (Table 1) show that the three doses examined, $0.2 ; 0.4$ and $0.6 \mathrm{~mL}$, significantly reduced the cell division index when compared to the mitotic index observed for their respective controls, a condition that has been intensified in the ET $48 \mathrm{~h}$. For all three doses, the cell division index registered for the ET $24 \mathrm{~h}$ was not statistically different from the values found in the ET $48 \mathrm{~h}$. According to Gomes et al. (2013), inhibition of cell division caused by chemical compounds in normal cell lines without any mutation and/or cell changes causes malfunction of a tissue because it does not allow the replacement of cells, alter protein production and thus result in malfunction of the organ where it is located.

Table 2 lists the mitotic spindle aberrations and micronucleus found in root meristem cells of $A$. cepa treated with water and food flavorings of Passion Fruit and Vanilla.

The results in Table 2 show that all three doses, $0.2 ; 0.4$ and $0.6 \mathrm{~mL}$ of passion fruit flavoring, at ET $24 \mathrm{~h}$ and $48 \mathrm{~h}$, promoted alterations in mitotic spindle - colchicine metaphase and anaphase/telophase bridges - and formation of micronuclei in statistically significant number of cells of $A$. cepa roots. It is important to emphasize that even at the dose of $0.2 \mathrm{~mL}$, considered ideal for use according to the manufacturer, the passion fruit additive promoted

Table 1. Number of observed cells for each stage of the cell cycle in root meristem tissue of Allium cepa treated with water and synthetic flavorings Passion fruit and Vanilla at doses of 0.2, 0.4 and $0.6 \mathrm{~mL}$ at the exposure times of 24 and 48 hours.

\begin{tabular}{|c|c|c|c|c|c|c|c|c|}
\hline \multicolumn{9}{|c|}{ PASSION FRUIT FLAVORING } \\
\hline TG/Dose & ET & TCII & $\mathbf{P}$ & $\mathbf{M}$ & $\mathbf{A}$ & $\mathbf{T}$ & TCD & MI (\%) \\
\hline \multirow{3}{*}{$0.2 \mathrm{~mL}$} & $\mathrm{CO}$ & 4,660 & 211 & 75 & 39 & 15 & 340 & $6.8^{\mathrm{a}}$ \\
\hline & $24 \mathrm{~h}$ & 4,696 & 147 & 85 & 58 & 14 & 304 & $6.4^{\mathrm{a}}$ \\
\hline & $48 \mathrm{~h}$ & 4,937 & 18 & 25 & 17 & 03 & 63 & $1.2^{\mathrm{b}}$ \\
\hline \multirow{3}{*}{$0.4 \mathrm{~mL}$} & $\mathrm{CO}$ & 4,564 & 139 & 123 & 103 & 71 & 436 & $8.7^{\mathrm{a}}$ \\
\hline & $24 \mathrm{~h}$ & 4,846 & 69 & 55 & 29 & 01 & 154 & $3.1^{\mathrm{b}}$ \\
\hline & $48 \mathrm{~h}$ & 4,955 & 29 & 14 & 01 & 01 & 45 & $0.9^{\mathrm{b}}$ \\
\hline \multirow{3}{*}{$0.6 \mathrm{~mL}$} & $\mathrm{CO}$ & 4,228 & 416 & 170 & 122 & 64 & 772 & $15.4^{\mathrm{a}}$ \\
\hline & $24 \mathrm{~h}$ & 4,894 & 58 & 31 & 10 & 07 & 106 & $2.1^{\mathrm{b}}$ \\
\hline & $48 \mathrm{~h}$ & 4,952 & 25 & 11 & 10 & 02 & 48 & $0.9^{\mathrm{b}}$ \\
\hline \multicolumn{9}{|c|}{ VANILLA FLAVORING } \\
\hline TG/Dose & ET & TCII & $\mathbf{P}$ & $\mathbf{M}$ & $\mathbf{A}$ & $\mathbf{T}$ & TCD & MI (\%) \\
\hline \multirow{3}{*}{$0.2 \mathrm{~mL}$} & $\mathrm{CO}$ & 4,103 & 484 & 235 & 145 & 33 & 897 & $17.9^{\mathrm{a}}$ \\
\hline & $24 \mathrm{~h}$ & 4,736 & 188 & 44 & 18 & 14 & 264 & $5.3^{\mathrm{b}}$ \\
\hline & $48 \mathrm{~h}$ & 4,892 & 63 & 20 & 11 & 14 & 108 & $2.1^{\mathrm{b}}$ \\
\hline \multirow{3}{*}{$0.4 \mathrm{~mL}$} & $\mathrm{CO}$ & 4,579 & 276 & 62 & 64 & 19 & 421 & $8.4^{\mathrm{a}}$ \\
\hline & $24 \mathrm{~h}$ & 4,891 & 62 & 24 & 07 & 16 & 109 & $2.2^{\mathrm{b}}$ \\
\hline & $48 \mathrm{~h}$ & 4,948 & 21 & 19 & 04 & 08 & 52 & $1.0^{\mathrm{b}}$ \\
\hline \multirow{3}{*}{$0.6 \mathrm{~mL}$} & $\mathrm{CO}$ & 4,672 & 222 & 144 & 130 & 32 & 498 & $10.0^{\mathrm{a}}$ \\
\hline & $24 \mathrm{~h}$ & 4,846 & 61 & 36 & 30 & 27 & 154 & $3.1^{\mathrm{b}}$ \\
\hline & $48 \mathrm{~h}$ & 4,948 & 11 & 22 & 06 & 13 & 52 & $1.0^{\mathrm{b}}$ \\
\hline
\end{tabular}

TG: Treatment group; TCII: Total number of cells in interfase and of undifferentiated cells; P: Prophase; M: Metaphase; A: Anaphase; T: Telophase; ET: Exposure Time; CO: Control; MI: Mitotic Index; TCD: Total number of dividing cells. Within the same treatment; MI values followed by different letters are significantly different at $5 \%$ by $\chi^{2}$ test. 
Table 2. Mitotic spindle alterations and micronuclei observed in root meristem cells of Allium cepa treated with water and synthetic flavorings of Passion Fruit at doses of 0.2, 0.4 and $0.6 \mathrm{~mL}$, and Vanilla at the dose $0.6 \mathrm{~mL}$ at the exposure times of 24 and 48 hours.

\begin{tabular}{|c|c|c|c|c|c|c|c|}
\hline \multicolumn{8}{|c|}{ PASSION FRUIT FLAVORING } \\
\hline $\begin{array}{c}\text { TG/Dose } \\
(\mathrm{mL})\end{array}$ & ET & $\begin{array}{l}\text { Colchicine } \\
\text { metaphase }\end{array}$ & $\begin{array}{c}\text { Anaphase } \\
\text { bridge }\end{array}$ & $\begin{array}{c}\text { Telophase } \\
\text { bridge }\end{array}$ & Micronuclei & $\begin{array}{c}\text { Binucleate } \\
\text { cell }\end{array}$ & TAC \\
\hline \multirow{3}{*}{0.2} & $\mathrm{CO}$ & 01 & 00 & 00 & 00 & 00 & $01^{\mathrm{a}}$ \\
\hline & $24 \mathrm{~h}$ & 34 & 18 & 05 & 43 & 00 & $100^{\mathrm{b}}$ \\
\hline & $48 \mathrm{~h}$ & 07 & 00 & 00 & 11 & 00 & $18^{\mathrm{c}}$ \\
\hline \multirow{3}{*}{0.4} & $\mathrm{CO}$ & 00 & 01 & 00 & 00 & 00 & $01^{\mathrm{a}}$ \\
\hline & $24 \mathrm{~h}$ & 27 & 12 & 13 & 58 & 00 & $110^{\mathrm{b}}$ \\
\hline & $48 \mathrm{~h}$ & 05 & 00 & 00 & 09 & 00 & $14^{\mathrm{c}}$ \\
\hline \multirow{3}{*}{0.6} & $\mathrm{CO}$ & 00 & 01 & 00 & 00 & 00 & $01^{\mathrm{a}}$ \\
\hline & $24 \mathrm{~h}$ & 24 & 13 & 13 & 28 & 02 & $78^{\mathrm{b}}$ \\
\hline & $48 \mathrm{~h}$ & 01 & 00 & 00 & 10 & 00 & $11^{\mathrm{c}}$ \\
\hline \multicolumn{8}{|c|}{ VANILLA FLAVORING } \\
\hline $\begin{array}{l}\text { Dose } \\
(\mathrm{mL})\end{array}$ & ET & $\begin{array}{l}\text { Colchicine } \\
\text { metaphase }\end{array}$ & $\begin{array}{c}\text { Anaphase } \\
\text { bridge }\end{array}$ & $\begin{array}{c}\text { Telophase } \\
\text { bridge }\end{array}$ & Micronuclei & $\begin{array}{c}\text { Binucleate } \\
\text { cell }\end{array}$ & TAC \\
\hline \multirow{3}{*}{0.6} & $\mathrm{CO}$ & 00 & 00 & 00 & 02 & 00 & $02^{\mathrm{a}}$ \\
\hline & $24 \mathrm{~h}$ & 09 & 09 & 07 & 22 & 00 & $47^{\mathrm{b}}$ \\
\hline & $48 \mathrm{~h}$ & 00 & 00 & 01 & 18 & 99 & $19^{c}$ \\
\hline
\end{tabular}

TG: Group Treatment; ET: Exposure Time; CO: Control; TAC: Total Cell Alterations. Values followed by different letters are significantly different at $5 \%$ by $\chi^{2}$ test.

the development of cellular alterations at significant numbers. Although the dose of $0.2 \mathrm{~mL}$ of this flavoring was not cytotoxic under the conditions of this study, it was genotoxic to cells of the test system used.

As shown in Table 2, only the dose of $0.6 \mathrm{~mL}$, at both ET evaluated, caused mitotic spindle aberrations and micronuclei in the cells of the test system. Still in this table, for the genotoxic doses of the two flavorings, at the ET $48 \mathrm{~h}$, the number of cellular alterations is significantly lower compared to the number observed for their respective ET $24 \mathrm{~h}$. This result confirms the results in Table 1, where the number of dividing cells for the doses of $0.2 ; 0.4$ and $0.6 \mathrm{~mL}$ of Passion Fruit and $0.6 \mathrm{~mL}$ of Vanilla was significantly lower compared to their respective ET $24 \mathrm{~h}$.

Türkoğlu (2007) argues that cells with mitotic spindle alterations and/or chromosomal breaks are likely to generate daughter cells with different chromosomal number, which impairs the functioning of the tissue where they are located. Such changes if not repaired or discarded can alter the cell cycle control mechanism, thus leading to the uncontrolled inhibition or proliferation of cells.

Marques et al. (2015) investigated toxicity at cellular level of flavorings of chocolate, strawberry and condensed milk using root meristem cells of $A$. cepa, and reported that these three substances, in the same way as the aroma and flavor additives studied herein, were cytotoxic to root meristems, as they caused significant reduction of the mitotic index of the cells of the tissues analyzed. Nevertheless, none of these flavorings evaluated by these researchers promoted cell aberrations of the test system used.

In the scientific literature, there are studies evaluating toxicity of some constituents of the classes of chemical compounds that may be present in the formulation of food flavorings in general. Among the preservatives are potassium benzoate, sodium benzoate, potassium nitrate (Brasil, 1999), which, according to Mpountoukas et al. (2010) and Zequin et al. (2011), were clastogenic, mutagenic, and cytotoxic to normal human peripheral blood cells; boric acid, citric acid, potassium citrate and sodium citrate (Brasil, 1999) which, in agreement with Tükoğlu (2007), were cytotoxic to root meristems cells of $A$. cepa.

For the class of diluents, Demir et al. (2010) found that benzoic alcohol at higher concentrations promoted significant damage to the mitotic spindle in human peripheral blood cells. In turn, a gene mutation assay in rat lymphoma showed that the diluent diacetyl (2,3-butadione) caused significant damage to loci of the chromosome 11 of these cells, causing loss of expression of the genes for thymidine kinase enzyme (Whittaker et al., 2008). It also led to the replacement of thymine with guanine in euchromatin, and the disruption of hydrogen and disulfide bonds in the tertiary structure of enzymes involved in cell division in mice cells (More et al., 2012).

Meanwhile, to date, the data obtained by these researchers cannot be directly attributed to the results obtained herein for flavorings Passion Fruit and Vanilla, once we have no detailed information on what chemical compounds representing preservatives and diluents in the chemical composition of these food additives.

\section{Conclusion}

The doses of $0.2 \mathrm{~mL}$ (ET 48h), 04 and $0.6 \mathrm{~mL}$ (ET 24 and $48 \mathrm{~h}$ ) of the passion fruit flavoring, and the doses of $0.2,0.4$, and $0.6 \mathrm{~mL}$ (ET 24 and $48 \mathrm{~h}$ ) of the additive vanilla were cytotoxic to root meristem cells of $A$. cepa. 
The three doses of passion fruit flavoring (ET 24 and $48 \mathrm{~h}$ ) and the dose of $0.6 \mathrm{~mL}$ of vanilla were genotoxic to the cell test system used.

The results allow us to infer that although the use of flavorings in food is permitted by food surveillance agencies, it is of great importance a more detailed analysis of the toxic potential of these additives, with emphasis on Vanilla and Passion Fruit, since these flavoring solutions are present in many processed foods and are freely traded in retail markets and websites specialized in the sale of food additives.

\section{References}

BRASIL. Agência Nacional de Vigilância Sanitária -ANVISA, 2007 [viewed 08 February 2014]. Resolucão da diretoria colegiada RDC $n^{o}$. 05, de 15 de Janeiro de 2007. Brasília: ANVISA. Available from: http://www.anvisa.gov.br/legis/resol/2007/rdc/02_170107rdc.pdf.

BRASIL. Ministério da Saúde - MS. Agência Nacional de Vigilância Sanitária-ANVISA, 1999 [viewed 13 April 2014]. Regulamento técnico sobre aditivos aromatizantes/aroma. Resolução $n^{\circ} 104$ de 14 de maio de 1999. Brasília: MS. Available from: http://www. engetecno.com.br/port/legislacao/norqual_aditivos_aromatizantes.htm

CARDOSO, G.H.S., DANTAS, E.B.S., SOUSA, F.R. and PERON, A.P., 2014. Cytotoxicity of aqueous extracts of Rosmarinus officinalis L. (Labiatae) in plant test system. Brazilian Journal of Biology = Revista Brasileira de Biologia, vol. 74, no. 4, pp. 886-889. http:// dx.doi.org/10.1590/1519-6984.07313. PMid:25627599.

CARITÁ, R. and MARIN-MORALES, M.A., 2008. Induction of chromosome aberrations in the Allium cepa test system caused by the exposure of seeds to industrial effluents contaminated with azo dyes. Chemosphere, vol. 72, no. 5, pp. 722-725. http://dx.doi. org/10.1016/j.chemosphere.2008.03.056. PMid:18495201.

DEMIR, E., KOCAOGLU, S. and KAYA, R., 2010. Assessment genotoxic effects of benzyl derivatives by comet assay. Food and Chemical Toxicology, vol. 48, no. 5, pp. 1239-1242. http://dx.doi. org/10.1016/j.fct.2010.02.016. PMid:20170703.

GOMES, K.M.S., OLIVEIRA, M.V.G.A., CARVALHO, F.R.S., MENEZES, C.C. and PERON, A.P., 2013. Citotoxicity of food dyes sunset yellow (E-110), bordeax red (E-123), and tatrazine yellow (E-102) on Allium cepa L root meristematic cells. Ciência e Tecnologia de Alimentos, vol. 33, no. 1, pp. 218-223. http://dx.doi. org/10.1590/S0101-20612013005000012910.

GUERRA, M. and SOUZA, M.J., 2002. Como observar os cromossomos: um guia de técnicas em citogenética vegetal, animal e humana. Ribeirao Preto: FUNPEC.

HERRERO, O., MARTÍN, J.P., FREIRE, P.F., LÓPEZ, L.C., PEROPADRE, A. and HAZEN, M.J., 2012. Toxicological evaluation of three contaminant of emerging concern by use of Allium cepa test. Mutation Research/Genetic Toxicology and Environmental Mutagenesis, vol. 743, no. 1-2, pp. 24-34. http://dx.doi.org/10.1016/j. mrgentox.2011.12.0282122. PMid:22249112.

KOCA, N., ERBAY, Z. and KAYMAK-ERTEKIN, F., 2015. Effects of spray-drying conditions on the chemical, physical, and sensory properties of cheese powder. Journal of Dairy Science, vol. 98, no. 5, pp. 2934-2943. http://dx.doi.org/10.3168/jds.2014-9111. PMid:25771045.

KONISHI, Y., HAYASHI, S.M. and FUKUSHIMA, S., 2014. Regulatory forum opinion piece*: supporting the need for international harmonization of safety assessments for food flavoring substance.
Toxicologic Pathology, vol. 42, no. 6, pp. 949-953. http://dx.doi. org/10.1177/0192623313495603. PMid:23881932.

LACERDA, L.P., MALAQUIAS, G. and PERON, A.P., 2014. Antiproliferative action of aqueous extracts of Hymenaea stigonocarpa Mart. (Fabaceae) on the cell cycle of Allium cepa L. Anais da Academia Brasileira de Ciencias, vol. 86, no. 3, pp. 1147-1150. http://dx.doi.org/10.1590/0001-3765201420130163. PMid:25029361

MARQUES, G.S., SILVA, S.I.O., SOUSA, J.M.C., FERREIRA, P.M.P. and PERON, A.P., 2015. Cytotoxicity and mutagenic potential of liquid synthetic food flavoring evaluated individually and in association. Food Science and Technology, vol. 35, no. 1, pp. 183-188.

MORE, S.S., RAZA, A. and VINCE, R., 2012. The butter flavorant, diacetyl, forms a covalent adduct with 2-deoxyguanosine, uncoils DNA, and leads to cell death. Journal of Agricultural and Food Chemistry, vol. 60, no. 12, pp. 3311-3317. http://dx.doi.org/10.1021/ jf300180e. PMid:22385266.

MPOUNTOUKAS P., PANTAZAKI A., KOSTARELI E., CHRISTODOULOU P., KARELID., POLILIOU S. and LIALIARIS, T., 2010. Cytogenetic evaluation and DNA interaction studies of the food colorants amaranth, erythrosine and tartrazine. Food Chemical and Toxicology, vol. 48, no. 10, pp. 2934-2944. http:// dx.doi.org/10.1016/fet.2010.07.030111219.

NEVES E.S., FERREIRA P.M.P., LIMA LH G.M. and PERON A.P., 2014. Action of Aqueous Extracts of Phyllanthus niruri L. (Euphorbiaceae) leaves on Meristematic Root Cells of Allium cepa $\mathrm{L}$. Anais da Academia Brasileira de Ciências, vol. 86, no. 1, pp. 11311135. http://dx.doi.org/10.1590/0001-373765201420130170383914.

OLIVEIRA, M.V.A., ALVES, D.D.L., LIMA, L.H.G.M., CASTRO, J.M.C. and PERON, A.P., 2013. Cytotoxicity of erytrosine (E-127), brilliant blue (E-133) and red 40 (E-129) food dyes plant test system. Acta Scientiarum Biological Science, vol. 35, no. 4, pp. 557-562. http://dx.doi.org/10.4025/actascibiolsci.v35i4.1841945.

TABREZ, S., SAHKIL, S., UROOJ, M., DAMANHORI, G.A., ABUZENADAH, A.M. and AHMAD, D., 2011. Genotoxicity testing and biomarker studies on surface water: an over view of the techniques and their efficacies. Journal Environmental Science Health. Part C, vol. 29, no. 3, pp. 250-275. http://dx.doi.org/10.1 080/10590501.2011.601849464716.

TÜRKOĞLU, Ş., 2007. Genotoxicity of five food preservatives tested on root tips of Allium cepa L. Mutation Research, vol. 626, no. 1-2, pp. 4-14. http://dx.doi.org/10.1016/j.mrgentox.2006.07.006. PMid:17005441.

WHITTAKER P., CLARKE J.J., SAN R.H., BEGLEY T.H. and DUNKEL V.C., 2008. Evaluation of the butter flavoring chemical diacetyl and a fluorochemical paper additive for mutagenicity and toxicity using the mammalian cell gene mutation assay in L5178Y mouse lymphoma cells. Food Chemical and Toxicology, vol. 46, no. 8, pp. 2928-2933. http://dx.doi.org/10.1016/j.fct.2008.06.001262723.

XU, Z., GU, C., WANG, K., JU, J., WANG, H., RUAN, K. and FENG, Y., 2015. Arctigenic acid, the key substance responsible for the hypoglycemic activity of Fructus Arctii. Phytomedicine, vol. 22, no. 1, pp. 128-137. http://dx.doi.org/10.1016/j.phymed.2014.11.006. PMid:25636881.

ZEQUIN, N., YÜZBAȘIOĞLU, D., UNAL, F., YILMAZ, S. and AKSOY, H., 2011. The evaluation of the genotoxicity of two food preservatives: sodium benzoate and potassium benzoate. Food Chemical and Toxicology, vol. 49, pp. 763-769. http://dx.doi. org/101016/j.fct.2010.11.040151620. 